\title{
Thermal Analysis for an Ultra High Temperature Gas-Cooled Reactor with Pebble Type Fuels
}

\author{
Motoo Fumizawa, Naoya Uchiyama, Takahiro Nakayama \\ Department of Mechanical Engineering, Shonan Institute of Technology, Fujisawa, Kanagawa, Japan
}

Email Address:

fumizawa@mech.shonan-it.ac.jp (M. Fumizawa),psn-man.lv.030@softbank.ne.jp (N. Uchiyama), 2991taka@gmail.com (T. Nakayama)

To cite this article:

Motoo Fumizawa, Naoya Uchiyama, Takahiro Nakayama. Thermal Analysis for an Ultra High Temperature Gas-Cooled Reactor with Pebble Type Fuels. International Journal of Energy and Power Engineering. Vol. 4, No. 4, 2015, pp. 189-196. doi: 10.11648/j.ijepe.20150404.11

\begin{abstract}
This study presents a predictive thermal-hydraulic analysis with packed spheres in a nuclear gas-cooled reactor core. The predictive analysis considering the effects of high power density and the some porosity value were applied as a design condition for an Ultra High Temperature Reactor (UHTR). The thermal-hydraulic computer code was developed and identified as PEBTEMP. The highest outlet coolant temperature of $1316^{\circ} \mathrm{C}$ was achieved in the case of an UHTREX at LASL, which was a small scale UHTR using hollow-rod as a fuel element. In the present study, the fuel was changed to a pebble type, a porous media. Several calculation based on HTGR-GT300 through GT600 were $4.8 \mathrm{w} / \mathrm{cm}^{3}$ through $9.6 \mathrm{w} / \mathrm{cm}^{3}$, respectively. As a result, the relation between the fuel temperature and the power density was obtained under the different system pressure and coolant outlet temperature. Finally, available design conditions are selected.
\end{abstract}

Keywords: Thermal Hydraulics, Ultra High Temperature Reactor (UHTR), Pressure Drop, Porosity and Pebble Type Fuel

\section{Introduction}

Very high temperature gas-cooled reactor project is energetically developing the design study to establish $1,000{ }^{\circ} \mathrm{C}$ as a coolant outlet temperature and to realize the hydrogen production [1-2], where GIF is the Generation IV International Forum. For a long time, a fundamental design study has been carried out in the field of the high temperature gas-cooled reactor i.e. HTGR [3-8], which showed that a coolant outlet temperature was around $900{ }^{\circ} \mathrm{C}$. The interest of HTGR is increasing in many countries as a promising energy future option. There are currently two research reactors of THGR type that are being operated in Japan and China. The inherent safety of HTGR is due to the large heat capacity and negative temperature reactivity coefficient. The high temperature heat supply can achieve more effective utilization of nuclear energy. For example, high temperature heat supply can provide for hydrogen production, which is expected as an alternative energy source for oil. Also, outstanding thermal efficiency will be achieved at about $900{ }^{\circ} \mathrm{C}$ with a Brayton-cycle gas turbine plant.

However, the highest outlet coolant temperature of $1316^{\circ} \mathrm{C}$ had been achieved by UHTREX as shown in Figure 1, in Los Alamos Scientific Laboratory at the end of 1960's [3-4]. It was a small scale Ultra High Temperature Nuclear Reactor
(UHTR). The coolant outlet temperature would be higher than $1000^{\circ} \mathrm{C}$ in the UHTR. The UHTREX adopted the hollow rod type fuel; the highest fuel temperature was $1,582{ }^{\circ} \mathrm{C}$, which indicated that the value was over the current design limit. According to the handy calculation, it was derived that the pebble type fuel was superior to the hollow type in the field of fuel surface heat transfer condition [9].In the present study, the fuels have changed to the pebble type so called the porous media. In order to compare the present pebble bed reactor and UHTREX, a calculation based on HTGR-GT300 was carried out in the similar conditions with UHTREX i.e. the inlet coolant temperature of $871^{\circ} \mathrm{C}$, system pressure of $3.45 \mathrm{MPa}$ and power density of $1.3 \mathrm{w} / \mathrm{cm}^{3}$. The main advantage of the pebble bed reactor (PBR) is that high outlet coolant temperature can be achieved due to its large cooling surface and high heat transfer coefficient that have the possibility to get high thermal efficiency. Besides, the fuel loading and discharging procedures are simplified; the PBR system makes it possible that the frequent load and discharge are easier than the other reactor system loaded block type fuel without reactor shutdown. This report presents thermal-hydraulic calculated results for a concept design PBR system of 300MWth of the modular HTGR-GT300 with the pebble types of fuel element 
as shown in Figure 2. A calculation for comparison with UHTREX have been carried out and presented as well.

\section{Reactor Description}

\subsection{Concept of Modular HTGR-GT300, GT600 and GT600}

A concept of pebble-bed type HTGR are shown in Figures 2 and 3 with the main nuclear and thermal-hydraulic specifications presented in Table 1. In the case that the thermal power is $300 \mathrm{MW}$ (GT-300), the average power density changes to $4.8 \mathrm{MW} / \mathrm{m}^{3}$. The coolant gas enters from the outer shell of the primary coolant coaxial tube to the pressure vessel at temperature of $550^{\circ} \mathrm{C}$ and pressure of $6 \mathrm{MPa}$, follows the peripheral region of side reflectors up to the top and goes downward through the reactor active core. The outlet coolant goes out through the inner shell of primary coolant tube at temperature of $900^{\circ} \mathrm{C}$. The cylindrical core is formed by the blocks of graphite reflector with the height of $9.4 \mathrm{~m}$ and the diameter of $2.91 \mathrm{~m}$. There exist holes in the reflector that some of them used for control rod channels and the others used for boron ball insertion in case of an accident. In the case that the thermal powers are 450MW (GT450) and 600MW (GT600), the average power densities change to $7.2 \mathrm{MW} / \mathrm{m}^{3}$ and 9.6 $\mathrm{MW} / \mathrm{m}^{3}$, respectively.

\subsection{Fuel Element}

The two types of pebble fuel elements, consisting of fuel and moderator, are shown in Figure 4. One is a solid type where radius of inner graphite $r_{c o}=0$, and the other is a shell type fuel element. The fuel compacts are a mixture of coated particles [9].

\section{Thermlhydraulic Analysis}

\subsection{PEPTEMP Code}

A one-dimensional thermal-hydraulic computer code was developed that was named PEPTEMP [5] as shown in Figure 5. The code solves for the temperature of fuel element, coolant gas and core pressure drop using assumed power, power distribution, inlet and outlet temperature, the system pressure, fuel size and fuel type as input data.

The options for fuel type are of the pebble type; the multi holes block type and the pin-in-block type. The power distribution for cases of cosine and exponential is available., The users can calculate for the other distributions by preparing the input file.

The maximum fuel temperature will be calculated in PEPTEMP as follows:

$$
T_{\max }(z)=T_{i n}+\Delta T_{c l}(z)+\Delta T_{\text {film }}(z)+\Delta T_{s l}(z)+\Delta T_{c o m}
$$

where $T_{\max }(z)$ : fuel temperature at the center of fuel element i.e. the maximum fuel temperature; $\Delta T_{c l}$ : gas temperature increment from inlet to height $z ; T_{i n}$ : gas inlet temperature; $\Delta T_{\text {film }}(z)$ : temperature difference between fuel element surface and coolant gas at $z ; \Delta T_{s l}(z)$ : temperature difference between fuel matrix outer surface and fuel element surface; $\Delta T_{\text {com }}(z)$ : temperature difference between fuel matrix outer surface and fuel center; $q^{\prime \prime \prime}$ : power density; $A_{f}$ : fuel element surface area; $z$ : axial distance from the top of the core; $C_{p}$ : coolant heat capacity.

\subsection{Temperature Difference in the Spherical Fuel Element}

Figure 4 shows fuel configuration of the solid type and the shell type fuel element. In the solid type, $\Delta \mathrm{T}_{\text {com }}$ is given as follows

$$
\Delta T_{c o m}(z)=T_{c o}-T_{c}=\frac{q^{\prime \prime \prime}(z) r_{c}^{2}}{6 \lambda_{c}}
$$

In the case of the shell type fuel element, $\Delta \mathrm{T}_{\text {com }}$ can be calculated by the following expression;

$$
\Delta T_{c o m}(z)=T_{c o}-T_{c}=\frac{q^{\prime \prime \prime}(z)}{6 \lambda_{c}}\left(r_{c}^{2}-3 r_{c o}^{2}+\frac{2 r_{c o}^{3}}{r_{c}}\right)
$$

\subsection{Film Temperature Difference}

The film temperature differences are calculated as follows;

$$
\Delta T_{\text {film }}=T_{s}-T_{c h}=\frac{q^{\prime \prime \prime}(z) r_{c}^{3}}{3 r_{s}^{2} h}
$$

\subsection{Heat Transfer Coefficient}

Heat transfer coefficient $h$ in Equation (4) is calculated using the following correlation [10]:

$$
\begin{aligned}
& h=0.68 \rho v_{s} C_{p} \operatorname{Re}^{-0.3} \operatorname{Pr}^{-0.66} \\
& \operatorname{Re}=\frac{\rho v_{s} d}{(1-\varepsilon) \mu}
\end{aligned}
$$

where, $\rho$ : coolant density; vs.: coolant velocity; Re: Reynolds number; Pr: Prandtl number; $\varepsilon$ : Porosity; d: fuel element diameter and $\mu$ : viscosity of fluid.

\section{Reactor structure of UHTREX}

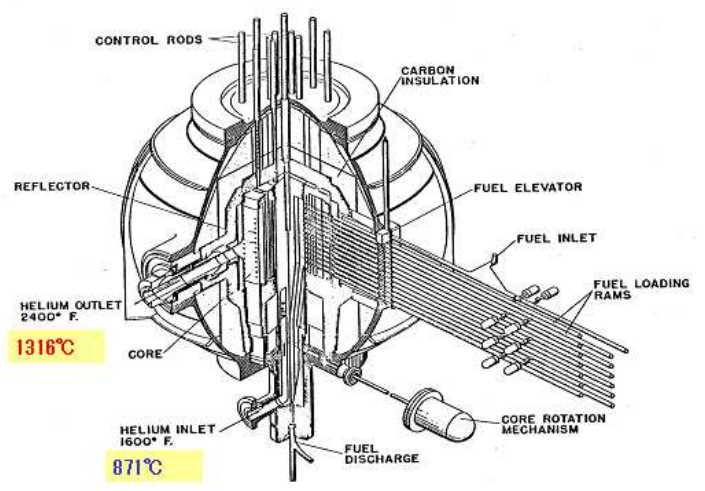

Fig. 1. Reactor structure of UHTREX, quoted from reference [3]. 
Table 1. Major nuclear and thermal-hydraulic specification.

\begin{tabular}{ll}
\hline Thermal power $(\mathrm{MW})$ & $300 / 450 / 600$ \\
Coolant & Helium \\
Inlet coolant temperature $(\mathrm{oC})$ & 550 \\
Outlet coolant temperature $(\mathrm{oC})$ & $900(900-1650 \mathrm{oC})$ \\
Coolant Pressure $(\mathrm{MPa})$ & $6.0(1-15 \mathrm{MPa})$ \\
Total coolant flow rate $(\mathrm{kg} / \mathrm{s})$ & $172.1 / 258.2 / 344.2$ \\
Core coolant flow rate $(\mathrm{kg} / \mathrm{s})$ & $165.2 / 247.8 / 320.8$ \\
Core diameter $(\mathrm{m})$ & 2.91 \\
Core height $(\mathrm{m})$ & 9.4 \\
Core fuel porosity $(-)$ & $0.39(0.26-0.50)$ \\
Average power density $(\mathrm{MW} / \mathrm{m} 3)$ & $4.8 / 7.2 / 9.6$ \\
Fuel type (for standard case) & $6 \mathrm{~cm}$ diameter pebble \\
\hline
\end{tabular}

\begin{tabular}{|l|}
\hline $\begin{array}{l}\text { The concept of } \\
\text { pebble bed type HTGR }\end{array}$ \\
Parameter study \\
considered as follows: \\
1. Thermal power \\
2. Porosity \\
3. System pressure \\
4. Outlet coolant \\
temperature \\
5. Solid, shell type fuel
\end{tabular}

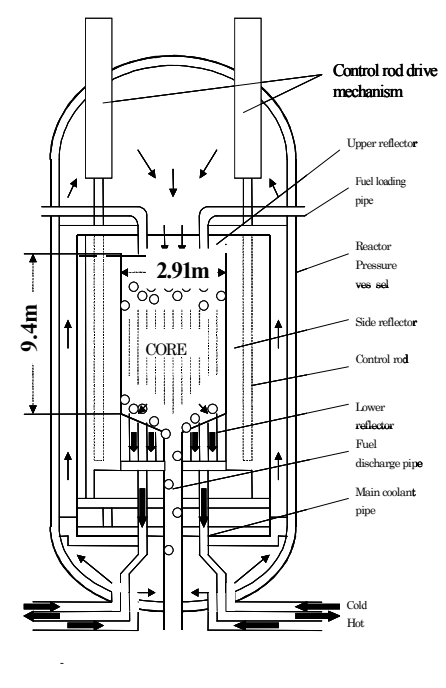

Fig. 2. A concept of pebble bed reactor of HTGR -GT300.

\section{Figure Core arrangement plane view}

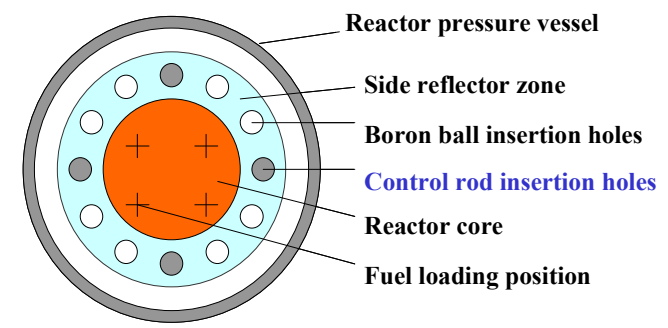

Four percent Coolant flows Control rod insertion holes. $W_{\text {eff }}:$ effective coolant flow rate that has dimensionless value due to the normalization by the total coolant flow rate. Maximum $W_{\text {eff }}$ is $\mathbf{0 . 9 6}$.

Fig. 3. Core arrangement plane view.

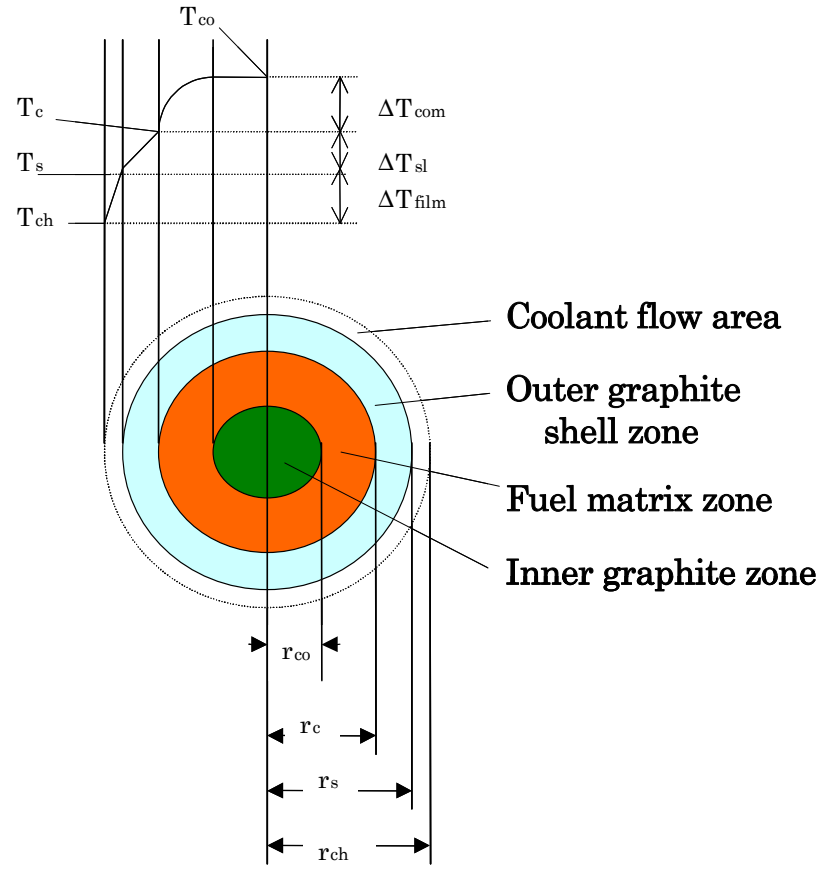

Fig. 4. Relation of shell type fuel element and temperature difference, in the case that no inner graphite zone is called the solid type, i.e., $r_{c o}=0$.

\section{Analysis method}

Fuel Temperature analysis code for Sphere fuel High Temperature gas-cooled reactor Unit cell model PEBTEMP

The option of thermal power distribution are as follows:

(1) Cosine

(2) exponential i.e. same fuel center temperature in axial

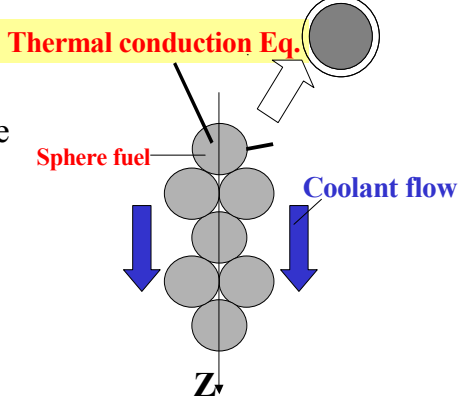

Fig. 5. Analysis method of thermal-hydraulic computer code PEPTEMP.

\begin{tabular}{||c||c||c||c||}
\hline \multirow{2}{*}{ Parameter } & \multicolumn{3}{|c||}{ Fuel element type } \\
\cline { 2 - 4 } & Hollow-rod & Multi-hole & Pebble-bed \\
\hline $\begin{array}{c}\text { Heat transfer area of } \\
\text { fuel (m } \mathbf{m}^{2}\end{array}$ & $\mathbf{7 7 7}$ & $\mathbf{1 0 7 3}$ & 3814 \\
\hline $\begin{array}{c}\text { Heat transfer } \\
\text { coefficient } \\
(\mathbf{W} / \mathbf{m} / \mathbf{K})\end{array}$ & $\mathbf{2 1 0 1}$ & $\mathbf{2 8 0 1}$ & 4037 \\
\hline
\end{tabular}

$\left(\mathbf{W} / \mathbf{m}^{2} \mathrm{~K}\right)$

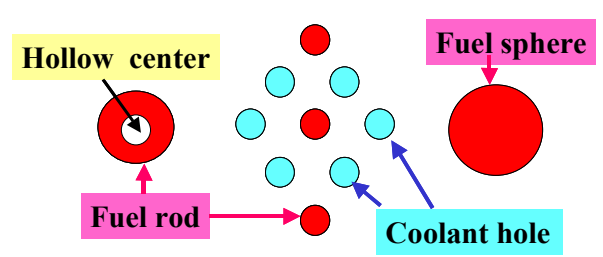

Fig. 6. Heat transfer performances in the small size reactor design by handy evaluation. 
Table 2. Analysis cases and fuel maximum temperature in the 300MW of thermal power i.e.GT300.

\begin{tabular}{|c|c|c|c|c|c|c|}
\hline Case & P(MPa) & Tout & $\varepsilon=0.26$ & $\varepsilon=0.39$ & $\varepsilon=0.40$ & $\varepsilon=0.50$ \\
\hline $\mathrm{A} 01$ & 1 & 900 & 983.7 & 1015.6 & 1019 & 1060.3 \\
\hline A02 & 1 & 1150 & 1209 & 1236.4 & 1239 & 1274.3 \\
\hline $\mathrm{A} 03$ & 1 & 1400 & 1446.7 & 1468.9 & 1471 & 1502 \\
\hline A04 & 1 & 1650 & 1688.9 & 1707.4 & 1709.6 & 1736.6 \\
\hline A05 & 5 & 900 & 983.7 & 1015.6 & 1019 & 1060.2 \\
\hline A06 & 5 & 1150 & 1209 & 1236.4 & 1239 & 1274.2 \\
\hline A07 & 5 & 1400 & 1446.7 & 1468.8 & 1471 & 1501.9 \\
\hline A08 & 5 & 1650 & 1688.8 & 1707.4 & 1709.6 & 1736.6 \\
\hline A09 & 6 & 900 & 983.7 & 1015.6 & 1019 & 1053.8 \\
\hline A10 & 6 & 1150 & 1209 & 1236.3 & 1239 & 1274.2 \\
\hline A11 & 6 & 1400 & 1446.7 & 1468.8 & 1471 & 1501.9 \\
\hline A12 & 6 & 1650 & 1688.8 & 1707.4 & 1709.6 & 1736.6 \\
\hline A13 & 10 & 900 & 983.7 & 1015.6 & 1019 & 1060.2 \\
\hline A14 & 10 & 1150 & 1209 & 1236.3 & 1238.9 & 1274.2 \\
\hline A15 & 10 & 1400 & 1446.7 & 1468.8 & 1470.9 & 1501.9 \\
\hline A16 & 10 & 1650 & 1688.8 & 1707.4 & 1709.6 & 1736.6 \\
\hline A17 & 15 & 900 & 983.7 & 1015.6 & 1019 & 1060.1 \\
\hline A18 & 15 & 1150 & 1208.9 & 1236.3 & 1238.9 & 1274.2 \\
\hline A19 & 15 & 1400 & 1446.7 & 1468.8 & 1470.9 & 1501.9 \\
\hline A 20 & 15 & 1650 & 1688.8 & 1707.4 & 1709.6 & 1736.6 \\
\hline
\end{tabular}

\subsection{Pressure Drop}

Pressure drop through the core expresses by the following correlation [6]:

$$
\begin{aligned}
& \mathrm{n}=0.22 \\
& K=1-0.26\left(1+n+3 \frac{1-\varepsilon}{\varepsilon}\right) \frac{d}{R} \\
& \operatorname{Re}_{p}=\frac{\rho v_{s} d}{\eta}
\end{aligned}
$$$$
\Delta P=6.986 \frac{(1-\varepsilon)^{n+1}}{\varepsilon^{3}} \operatorname{Re}_{p}^{-n} \rho v_{s}^{2} \frac{H}{d} K+\Delta P_{a}
$$

where, $H$ : core height; $R$ : core radius and $\Delta P_{a}$ : acceleration pressure drop.

\subsection{Effective Flow Rate Consideration}

As many blocks of graphite form the reflector, there exist gaps by which the coolant flow may pass through [11]. Actually, only one portion of coolant passes through the reactor core from the top to the bottom. This portion is called effective flow rate and can be calculated iteratively in the code. The empirical equation used in this code is as follows [11]:

$$
W_{\text {eff }}=0.98-0.012 \Delta P
$$

where, $W_{\text {eff: }}$ effective coolant flow rate that has dimensionless value due to the normalization by the total coolant flow rate.

$\Delta P$ : pressure drop through the core

\section{Calculation Results}

\subsection{Handy Calculation Results for Small Scale HTGR}

Before the main calculation, we have done the prediction study of the comparison of key factors of heat transfer in the small scale HTGR with three types of different fuel elements. They are the hollow-rod [3], the multi-hole [1,8] and the pebble-bed [10]. The small reactor thermal data are as follows; thermal power of $50 \mathrm{MW}$, power density of $2.5 \mathrm{MW} / \mathrm{m}^{3}$ and inlet/ outlet coolant temperature of $395{ }^{\circ} \mathrm{C} / 850{ }^{\circ} \mathrm{C}$, respectively. Figure 6 shows the results of heat transfer area in the core and heat transfer coefficient on the fuel surface. Heat transfer area of the pebble-bed is 5 times larger than that of the hollow-rod. Heat transfer coefficient of the pebble-bed is twice larger than that of the hollow-rod. Therefore heat transfer performance of pebble-bed is superior to other types of fuel elements.

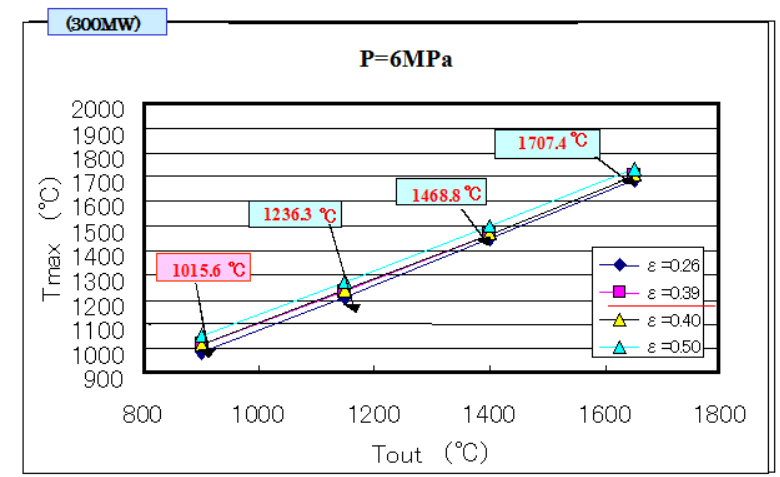

Fig. 7. Dependence of maximum fuel temperature on outlet coolant temperature for GT300 with different porosity and $W_{\text {eff }}=1$. 


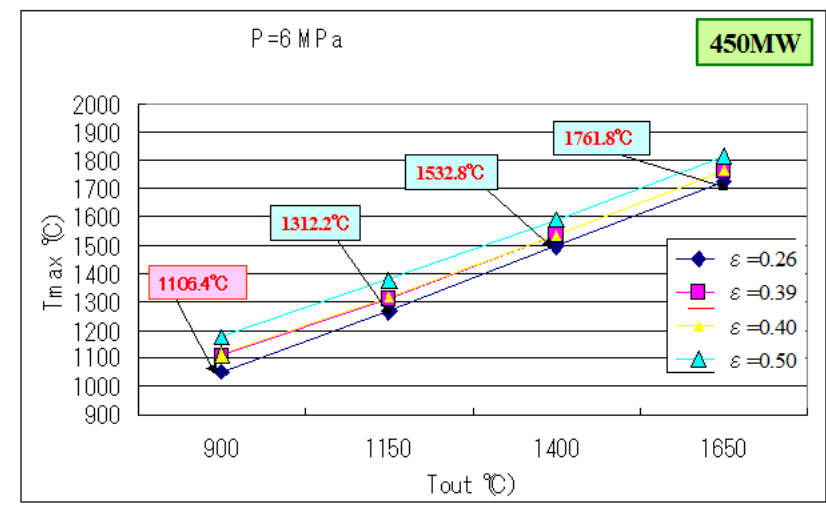

Fig. 8. Dependence of maximum fuel temperature on outlet coolant temperature for GT450 with different porosity and $W_{\text {eff }}=1$.

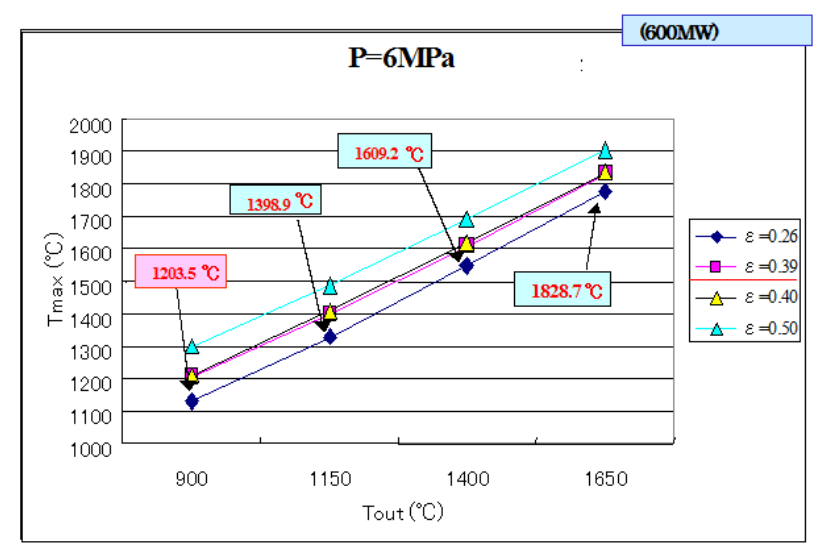

Fig. 9. Dependence of maximum fuel temperature on outlet coolant temperature for GT600 with different porosity and $W_{\text {eff }}=1$.

\subsection{Temperature Calculation for HTGR-GT300 to GT600}

Table 2 shows the 20 analysis cases and fuel maximum temperature in the $300 \mathrm{MW}$ of thermal power i.e.GT300. The system pressure ranges from $1 \mathrm{MPa}$ through $15 \mathrm{MPa}$. The system pressure does not have any effect on the fuel maximum temperature. Thus we focus our intension to 6 $\mathrm{MPa}$ of system pressure [1]. Figure 7, 8 and 9 show the dependence of maximum fuel temperature on outlet coolant temperature for GT300, GT450 and GT-600 with different porosity and $\mathrm{W}_{\mathrm{eff}}=1$. The maximum fuel temperature for GT600 is $168{ }^{\circ} \mathrm{C}$ higher than that for GT300 where the outlet coolant temperature is $900{ }^{\circ} \mathrm{C}$ and the porosity is 0.39 . The maximum fuel temperature for GT-600 is $163{ }^{\circ} \mathrm{C}$ higher than that for GT-300, where the outlet coolant temperature is 1150 ${ }^{\circ} \mathrm{C}$ and the porosity is 0.39 . The high porosity leads to low fuel maximum temperature.

\subsection{Pressure Drop Calculation for HTGR-GT300 to GT600}

Table 3 shows the 20 analysis cases and pressure drop $(\Delta P)$ in the core of $300 \mathrm{MW}$ of thermal power. The system pressure ranges from $1 \mathrm{MPa}$ through $15 \mathrm{MPa}$. The high system pressure leads to low-pressure drop in the core. In the case of $6 \mathrm{MPa}$ of system pressure, the $\Delta P$ changes from $40.2 \mathrm{kPa}$ to $16.7 \mathrm{kPa}$, where the $T_{\text {out }}$ increases from $900{ }^{\circ} \mathrm{C}$ to $1150{ }^{\circ} \mathrm{C}$. The $\Delta P$ changes from $16.7 \mathrm{kPa}$ to $6.3 \mathrm{kPa}$, where the porosity increases from 0.39 to 0.50 with $1150{ }^{\circ} \mathrm{C}$ of $T_{\text {out }}$. The high porosity leads to low-pressure drop. In the case of $15 \mathrm{MPa}$ of system pressure, the $\Delta P$ changes from $16.7 \mathrm{kPa}$ to $6.7 \mathrm{kPa}$, where the $T_{\text {out }}$ increases from $900{ }^{\circ} \mathrm{C}$ to $1150{ }^{\circ} \mathrm{C}$. The $\Delta P$ changes from $6.7 \mathrm{kPa}$ to $2.6 \mathrm{kPa}$, where the porosity increases from 0.39 to 0.50 with $1150{ }^{\circ} \mathrm{C}$ of $T_{\text {out }}$.

Table 4 shows the 20 analysis cases and pressure drop $(\Delta P)$ in the core of $450 \mathrm{MW}$ of thermal power. The system pressure ranges from $1 \mathrm{MPa}$ through $15 \mathrm{MPa}$. The high system pressure leads to low-pressure drop in the core. In the case of $6 \mathrm{MPa}$ of system pressure, the $\Delta P$ changes from $86.2 \mathrm{kPa}$ to $35.3 \mathrm{kPa}$, where the $T_{\text {out }}$ increases from $900{ }^{\circ} \mathrm{C}$ to $1150{ }^{\circ} \mathrm{C}$. The $\Delta P$ changes from $35.3 \mathrm{kPa}$ to $13.7 \mathrm{kPa}$, where the porosity increases from 0.39 to 0.50 with $1150{ }^{\circ} \mathrm{C}$ of $T_{\text {out }}$. The high porosity leads to low-pressure drop. In the case of $15 \mathrm{MPa}$ of system pressure, the $\Delta P$ changes from $35.3 \mathrm{kPa}$ to $14.7 \mathrm{kPa}$, where the $T_{\text {out }}$ increases from $900{ }^{\circ} \mathrm{C}$ to $1150{ }^{\circ} \mathrm{C}$. The $\Delta P$ changes from $14.7 \mathrm{kPa}$ to $5.5 \mathrm{kPa}$, where the porosity increases from 0.39 to 0.50 with $1150{ }^{\circ} \mathrm{C}$ of $T_{\text {out }}$.

Table 5 shows the 20 analysis cases and pressure drop $(\Delta P)$ in the core of $600 \mathrm{MW}$ of thermal power. The system pressure ranges from $1 \mathrm{MPa}$ through $15 \mathrm{MPa}$. The high system pressure leads to low-pressure drop in the core. In the case of $6 \mathrm{MPa}$ of system pressure, the $\Delta P$ changes from $147 \mathrm{kPa}$ to $60.8 \mathrm{kPa}$, where the $T_{\text {out }}$ increases from $900{ }^{\circ} \mathrm{C}$ to $1150{ }^{\circ} \mathrm{C}$. The $\Delta P$ changes from $60.8 \mathrm{kPa}$ to $23.5 \mathrm{kPa}$, where the porosity increases from 0.39 to 0.50 with $1150{ }^{\circ} \mathrm{C}$ of $T_{\text {out }}$. The high porosity leads to low-pressure drop. In the case of $15 \mathrm{MPa}$ of system pressure, the $\Delta P$ changes from $59.8 \mathrm{kPa}$ to $24.5 \mathrm{kPa}$, where the $T_{\text {out }}$ increases from $900{ }^{\circ} \mathrm{C}$ to $1150{ }^{\circ} \mathrm{C}$. The $\Delta P$ changes from $124.5 \mathrm{kPa}$ to $9.4 \mathrm{kPa}$, where the porosity increases from 0.39 to 0.50 with $1150{ }^{\circ} \mathrm{C}$ of $T_{\text {out }}$.

\section{Available pressure drop evaluation}

$$
\begin{aligned}
& \text { Weff } \geqq 0.70 \\
& \text { From eq.(11) } \\
& \Delta P \leqq 23.3 \mathrm{kPa}
\end{aligned}
$$

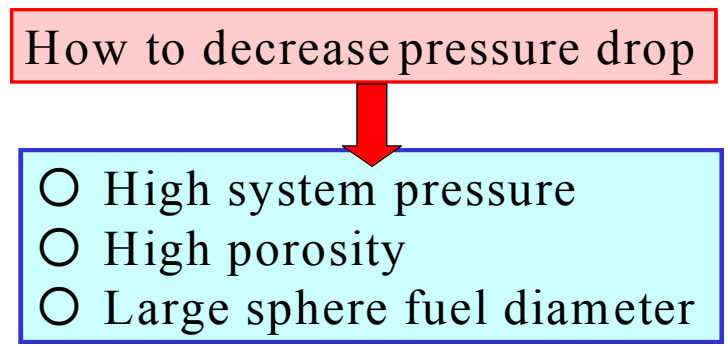

Fig. 10. The procedures to evaluate the pressure drop considering the available effective coolant flow rate. 
Table 3. Analysis cases and pressure drop in the GT300

\begin{tabular}{|c|c|c|c|c|c|c|}
\hline Case & P(MPa) & Tout & $\varepsilon=0.26$ & $\varepsilon=0.39$ & $\varepsilon=0.40$ & $\varepsilon=0.50$ \\
\hline A01 & 1 & 900 & $9.80 \mathrm{E}+02$ & $2.35 \mathrm{E}+02$ & $2.16 \mathrm{E}+02$ & $9.11 \mathrm{E}+01$ \\
\hline A02 & 1 & 1150 & $4.12 \mathrm{E}+02$ & $9.80 \mathrm{E}+01$ & $8.92 \mathrm{E}+01$ & $3.72 \mathrm{E}+01$ \\
\hline A03 & 1 & 1400 & $2.35 \mathrm{E}+02$ & $5.78 \mathrm{E}+01$ & $5.19 \mathrm{E}+01$ & $2.16 \mathrm{E}+01$ \\
\hline A04 & 1 & 1650 & $1.67 \mathrm{E}+02$ & $3.92 \mathrm{E}+01$ & $3.63 \mathrm{E}+01$ & $1.47 \mathrm{E}+01$ \\
\hline A05 & 5 & 900 & $1.96 \mathrm{E}+02$ & $4.80 \mathrm{E}+01$ & $4.41 \mathrm{E}+01$ & $1.86 \mathrm{E}+01$ \\
\hline A06 & 5 & 1150 & $8.23 \mathrm{E}+01$ & $1.96 \mathrm{E}+01$ & $1.76 \mathrm{E}+01$ & $7.55 \mathrm{E}+00$ \\
\hline A07 & 5 & 1400 & $4.80 \mathrm{E}+01$ & $1.18 \mathrm{E}+01$ & $1.08 \mathrm{E}+01$ & $4.41 \mathrm{E}+00$ \\
\hline A09 & 6 & 900 & $1.67 \mathrm{E}+02$ & $4.02 \mathrm{E}+01$ & $3.63 \mathrm{E}+01$ & $1.57 \mathrm{E}+01$ \\
\hline A10 & 6 & 1150 & $6.86 \mathrm{E}+01$ & $1.67 \mathrm{E}+01$ & $1.47 \mathrm{E}+01$ & $6.27 \mathrm{E}+00$ \\
\hline A11 & 6 & 1400 & $4.02 \mathrm{E}+01$ & $9.60 \mathrm{E}+00$ & $8.72 \mathrm{E}+00$ & $3.72 \mathrm{E}+00$ \\
\hline A12 & 6 & 1650 & $2.74 \mathrm{E}+01$ & $6.57 \mathrm{E}+00$ & $5.98 \mathrm{E}+00$ & $2.55 \mathrm{E}+00$ \\
\hline A13 & 10 & 900 & $9.80 \mathrm{E}+01$ & $2.45 \mathrm{E}+01$ & $2.16 \mathrm{E}+01$ & $9.21 \mathrm{E}+00$ \\
\hline A14 & 10 & 1150 & $4.12 \mathrm{E}+01$ & $9.80 \mathrm{E}+00$ & $9.02 \mathrm{E}+00$ & $3.82 \mathrm{E}+00$ \\
\hline A15 & 10 & 1400 & $2.45 \mathrm{E}+01$ & $5.78 \mathrm{E}+00$ & $5.29 \mathrm{E}+00$ & $2.25 \mathrm{E}+00$ \\
\hline A18 & 15 & 1150 & $2.74 \mathrm{E}+01$ & $6.66 \mathrm{E}+00$ & $6.08 \mathrm{E}+00$ & $2.55 \mathrm{E}+00$ \\
\hline A19 & 15 & 1400 & $1.57 \mathrm{E}+01$ & $3.82 \mathrm{E}+00$ & $3.53 \mathrm{E}+00$ & $1.47 \mathrm{E}+00$ \\
\hline A 20 & 15 & 1650 & $1.08 \mathrm{E}+01$ & $2.65 \mathrm{E}+00$ & $2.45 \mathrm{E}+00$ & $9.80 \mathrm{E}-01$ \\
\hline
\end{tabular}

Table 4. Analysis cases and pressure drop in the GT450.

\begin{tabular}{|c|c|c|c|c|c|c|}
\hline Case & P(MPa) & Tout & $\varepsilon=0.26$ & $\varepsilon=0.39$ & $\varepsilon=0.40$ & $\varepsilon=\mathbf{0 . 5 0}$ \\
\hline A01 & 1 & 900 & $2.16 \mathrm{E}+03$ & $5.19 \mathrm{E}+02$ & $4.70 \mathrm{E}+02$ & $1.96 \mathrm{E}+02$ \\
\hline A02 & 1 & 1150 & $8.82 \mathrm{E}+02$ & $2.16 \mathrm{E}+02$ & $1.96 \mathrm{E}+02$ & $8.13 \mathrm{E}+01$ \\
\hline A03 & 1 & 1400 & $5.10 \mathrm{E}+02$ & $1.27 \mathrm{E}+02$ & $1.08 \mathrm{E}+02$ & $4.70 \mathrm{E}+01$ \\
\hline A04 & 1 & 1650 & $3.53 \mathrm{E}+02$ & $8.43 E+01$ & $7.64 \mathrm{E}+01$ & $3.23 \mathrm{E}+01$ \\
\hline A05 & 5 & 900 & $4.31 \mathrm{E}+02$ & $1.08 \mathrm{E}+02$ & $9.41 \mathrm{E}+01$ & $3.92 \mathrm{E}+01$ \\
\hline A06 & 5 & 1150 & $1.76 \mathrm{E}+02$ & $6.32 \mathrm{E}+03$ & $3.82 \mathrm{E}+01$ & $1.67 \mathrm{E}+01$ \\
\hline A07 & 5 & 1400 & $1.08 \mathrm{E}+02$ & $2.45 \mathrm{E}+01$ & $2.25 \mathrm{E}+01$ & $9.51 \mathrm{E}+00$ \\
\hline A09 & 6 & 900 & $3.63 \mathrm{E}+02$ & $8.62 \mathrm{E}+01$ & $7.84 \mathrm{E}+01$ & $3.33 \mathrm{E}+01$ \\
\hline A 10 & 6 & 1150 & $1.47 \mathrm{E}+02$ & $3.53 \mathrm{E}+01$ & $3.23 \mathrm{E}+01$ & $1.37 \mathrm{E}+01$ \\
\hline A11 & 6 & 1400 & $8.62 \mathrm{E}+01$ & $2.06 \mathrm{E}+01$ & $1.86 \mathrm{E}+01$ & $7.94 \mathrm{E}+00$ \\
\hline A12 & 6 & 1650 & $5.88 \mathrm{E}+01$ & $1.37 \mathrm{E}+01$ & $1.27 \mathrm{E}+01$ & $5.39 \mathrm{E}+00$ \\
\hline A13 & 10 & 900 & $2.16 \mathrm{E}+02$ & $5.19 \mathrm{E}+01$ & $4.70 \mathrm{E}+01$ & $1.96 \mathrm{E}+01$ \\
\hline A14 & 10 & 1150 & $8.92 \mathrm{E}+01$ & $2.16 \mathrm{E}+01$ & $1.96 \mathrm{E}+01$ & $8.13 \mathrm{E}+00$ \\
\hline A 15 & 10 & 1400 & $5.19 \mathrm{E}+01$ & $1.27 \mathrm{E}+01$ & $1.18 \mathrm{E}+01$ & $4.70 \mathrm{E}+00$ \\
\hline A17 & 15 & 900 & $1.47 \mathrm{E}+02$ & $3.53 \mathrm{E}+01$ & $3.14 \mathrm{E}+01$ & $1.37 \mathrm{E}+01$ \\
\hline A18 & 15 & 1150 & $5.98 \mathrm{E}+01$ & $1.47 \mathrm{E}+01$ & $1.27 \mathrm{E}+01$ & $5.49 \mathrm{E}+00$ \\
\hline A19 & 15 & 1400 & $3.43 \mathrm{E}+01$ & $8.33 \mathrm{E}+00$ & $7.55 \mathrm{E}+00$ & $3.14 \mathrm{E}+00$ \\
\hline A 20 & 15 & 1650 & $2.35 \mathrm{E}+01$ & $5.68 \mathrm{E}+00$ & $5.19 \mathrm{E}+00$ & $2.16 \mathrm{E}+00$ \\
\hline
\end{tabular}

Table 5. Analysis cases and pressure drop in the GT600.

\begin{tabular}{|c|c|c|c|c|c|c|}
\hline Case & P(MPa) & Tout & $\varepsilon=0.26$ & $\varepsilon=0.39$ & $\varepsilon=\mathbf{0 . 4 0}$ & $\varepsilon=0.50$ \\
\hline A01 & 1 & 900 & $3.72 \mathrm{E}+03$ & $8.92 \mathrm{E}+02$ & $8.13 \mathrm{E}+02$ & $3.43 \mathrm{E}+02$ \\
\hline A02 & 1 & 1150 & $1.57 \mathrm{E}+03$ & $3.63 \mathrm{E}+02$ & $3.33 \mathrm{E}+02$ & $1.37 \mathrm{E}+02$ \\
\hline A03 & 1 & 1400 & $8.82 \mathrm{E}+02$ & $2.16 \mathrm{E}+02$ & $1.96 \mathrm{E}+02$ & $8.13 \mathrm{E}+01$ \\
\hline A04 & 1 & 1650 & $6.08 \mathrm{E}+02$ & $1.47 \mathrm{E}+02$ & $1.27 \mathrm{E}+02$ & $5.59 \mathrm{E}+01$ \\
\hline A05 & 5 & 900 & $7.45 \mathrm{E}+02$ & $1.76 \mathrm{E}+02$ & $1.67 \mathrm{E}+02$ & $6.86 \mathrm{E}+01$ \\
\hline A06 & 5 & 1150 & $3.04 \mathrm{E}+02$ & $7.35 \mathrm{E}+01$ & $6.66 \mathrm{E}+01$ & $2.84 \mathrm{E}+01$ \\
\hline A07 & 5 & 1400 & $1.76 \mathrm{E}+02$ & $4.21 \mathrm{E}+01$ & $3.92 \mathrm{E}+01$ & $1.67 \mathrm{E}+01$ \\
\hline A09 & 6 & 900 & $6.17 \mathrm{E}+02$ & $1.47 \mathrm{E}+02$ & $1.37 \mathrm{E}+02$ & $5.68 \mathrm{E}+01$ \\
\hline A10 & 6 & 1150 & $2.55 \mathrm{E}+02$ & $6.08 \mathrm{E}+01$ & $5.59 \mathrm{E}+01$ & $2.35 \mathrm{E}+01$ \\
\hline A11 & 6 & 1400 & $1.47 \mathrm{E}+02$ & $3.53 \mathrm{E}+01$ & $3.23 \mathrm{E}+01$ & $1.37 \mathrm{E}+01$ \\
\hline A12 & 6 & 1650 & $9.80 \mathrm{E}+01$ & $2.45 \mathrm{E}+01$ & $2.25 \mathrm{E}+01$ & $9.31 \mathrm{E}+00$ \\
\hline A13 & 10 & 900 & $3.72 \mathrm{E}+02$ & $9.02 \mathrm{E}+01$ & $8.13 \mathrm{E}+01$ & $3.43 \mathrm{E}+01$ \\
\hline A14 & 10 & 1150 & $1.57 \mathrm{E}+02$ & $3.72 \mathrm{E}+01$ & $3.33 \mathrm{E}+01$ & $1.37 \mathrm{E}+01$ \\
\hline A 15 & 10 & 1400 & $8.92 \mathrm{E}+01$ & $2.16 \mathrm{E}+01$ & $1.96 \mathrm{E}+01$ & $8.13 \mathrm{E}+00$ \\
\hline A 17 & 15 & 900 & $2.55 \mathrm{E}+02$ & $5.98 \mathrm{E}+01$ & $5.49 \mathrm{E}+01$ & $2.25 \mathrm{E}+01$ \\
\hline A18 & 15 & 1150 & $9.80 \mathrm{E}+01$ & $2.45 \mathrm{E}+01$ & $2.25 \mathrm{E}+01$ & $9.41 \mathrm{E}+00$ \\
\hline A19 & 15 & 1400 & $5.98 \mathrm{E}+01$ & $1.47 \mathrm{E}+01$ & $1.27 \mathrm{E}+01$ & $5.49 \mathrm{E}+00$ \\
\hline A20 & 15 & 1650 & 4.12E+01 & $9.80 \mathrm{E}+00$ & $8.92 \mathrm{E}+00$ & $3.72 \mathrm{E}+00$ \\
\hline
\end{tabular}


Table 6. The available analysis cases in the GT300 considering the design limits.

\begin{tabular}{lllllll}
\hline Case & $\mathbf{P}(\mathbf{M P a})$ & Tout & $\mathbf{\varepsilon = 0 . 2 6}$ & $\mathbf{\varepsilon = 0 . 3 9}$ & $\mathbf{\varepsilon = 0 . 4 0}$ & $\mathbf{\varepsilon = 0 . 5 0}$ \\
\hline A01 & 1 & 900 & 983.7 & 1016 & 1019 & 1060 \\
A02 & 1 & 1150 & 1209 & 1236 & 1239 & 1274 \\
A05 & 5 & 900 & 983.7 & 1015.6 & 1019 & 1060.2 \\
A06 & 5 & 1150 & 1209 & 1236.4 & 1239 & 1274.2 \\
A09 & 6 & 900 & 983.7 & 1016 & 1019 & 1054 \\
A10 & 6 & 1150 & 1209 & 1236 & 1239 & 1274 \\
A13 & 10 & 900 & 983.7 & 1015.6 & 1019 & 1060.2 \\
A14 & 10 & 1150 & 1209 & 1236.3 & 1238.9 & 1274.2 \\
A17 & 15 & 900 & 983.7 & 1016 & 1019 & 1060 \\
A18 & 15 & 1150 & 1208.9 & 1236 & 1239 & 1274 \\
\hline
\end{tabular}

\begin{tabular}{|c|c|c|c|c|c|c|}
\hline Case & P(MPa) & Tout & $\varepsilon=0.26$ & $\varepsilon=0.39$ & $\varepsilon=0.40$ & $\varepsilon=0.50$ \\
\hline A03 & 1 & 1400 & & & & $2.16 \mathrm{E}+01$ \\
\hline A04 & 1 & 1650 & & & & $1.47 \mathrm{E}+01$ \\
\hline A05 & 5 & 900 & & & & $1.86 \mathrm{E}+01$ \\
\hline A06 & 5 & 1150 & & $1.96 \mathrm{E}+01$ & $1.76 \mathrm{E}+01$ & $7.55 \mathrm{E}+00$ \\
\hline A09 & 6 & 900 & & & & $1.57 \mathrm{E}+01$ \\
\hline A10 & 6 & 1150 & & $1.67 \mathrm{E}+01$ & $1.47 \mathrm{E}+01$ & $6.27 \mathrm{E}+00$ \\
\hline A13 & 10 & 900 & & & $2.16 \mathrm{E}+01$ & $9.21 \mathrm{E}+00$ \\
\hline A14 & 10 & 1150 & & $9.80 \mathrm{E}+00$ & $9.02 \mathrm{E}+00$ & $3.82 \mathrm{E}+00$ \\
\hline A17 & 15 & 900 & & $1.67 \mathrm{E}+01$ & $1.47 \mathrm{E}+01$ & $6.17 \mathrm{E}+00$ \\
\hline A18 & 15 & 1150 & & $6.66 \mathrm{E}+00$ & $6.08 \mathrm{E}+00$ & $2.55 \mathrm{E}+00$ \\
\hline
\end{tabular}

Design Limit of maximum fuel temperature $\left({ }^{\circ} \mathrm{C}\right)$ and pressure drop $(\mathrm{kPa})$ in $300 \mathrm{MW}$ thermal power

Design Limit

$\mathrm{Tmax} \leqq 1300^{\circ} \mathrm{C}$

$\Delta \mathrm{Pmax} \leqq 23.3 \mathrm{kPa}$

Table 7. The available analysis cases in the GT600 considering the design limits.

\begin{tabular}{lllllll}
\hline Case & $\mathbf{P}(\mathbf{M P a})$ & Tout & $\boldsymbol{\varepsilon}=\mathbf{0 . 2 6}$ & $\mathbf{\varepsilon = 0 . 3 9}$ & $\boldsymbol{\varepsilon}=\mathbf{0 . 4 0}$ & $\mathbf{\varepsilon}=\mathbf{0 . 5 0}$ \\
\hline A01 & 1 & 900 & 1130.3 & 1203.5 & 1210.5 & 1297.9 \\
A05 & 5 & 900 & 1130.3 & 1203.5 & 1210.5 & 1297.9 \\
A09 & 6 & 900 & 1130.3 & 1203.5 & 1210.4 & 1297.9 \\
A13 & 10 & 900 & 1130.3 & 1203.4 & 1210.4 & 1297.8 \\
A17 & 15 & 900 & 1130.3 & 1203.4 & 1210.4 & 1297.8 \\
\hline
\end{tabular}

\begin{tabular}{|c|c|c|c|c|c|c|}
\hline Case & P(MPa) & Tout & $\varepsilon=0.26$ & $\varepsilon=0.39$ & $\varepsilon=0.40$ & $\varepsilon=0.50$ \\
\hline A07 & 5 & 1400 & & & & $1.67 \mathrm{E}+01$ \\
\hline A08 & 5 & 1650 & & & & $1.08 \mathrm{E}+01$ \\
\hline $\mathrm{A} 10$ & 6 & 1150 & & & & $2.35 \mathrm{E}+01$ \\
\hline A11 & 6 & 1400 & & & & $1.37 \mathrm{E}+01$ \\
\hline A12 & 6 & 1650 & & & $2.25 \mathrm{E}+01$ & $9.31 \mathrm{E}+00$ \\
\hline A14 & 10 & 1150 & & & & $1.37 \mathrm{E}+01$ \\
\hline A15 & 10 & 1400 & & $2.16 \mathrm{E}+01$ & $1.96 \mathrm{E}+01$ & $8.13 \mathrm{E}+00$ \\
\hline A16 & 10 & 1650 & & $1.47 \mathrm{E}+01$ & $1.37 \mathrm{E}+01$ & $5.59 \mathrm{E}+00$ \\
\hline A17 & 15 & 900 & & & & $2.25 \mathrm{E}+01$ \\
\hline A18 & 15 & 1150 & & & $2.25 \mathrm{E}+01$ & $9.41 \mathrm{E}+00$ \\
\hline A19 & 15 & 1400 & & $1.47 \mathrm{E}+01$ & $1.27 \mathrm{E}+01$ & $5.49 \mathrm{E}+00$ \\
\hline A20 & 15 & 1650 & & $9.80 \mathrm{E}+00$ & $8.92 \mathrm{E}+00$ & $3.72 \mathrm{E}+00$ \\
\hline
\end{tabular}

Design Limit of maximum fuel temperature $\left({ }^{\circ} \mathrm{C}\right)$ and pressure drop $(\mathrm{kPa})$ in $600 \mathrm{MW}$ thermal power

Design Limit:

$\operatorname{Tmax} \leqq 1300^{\circ} \mathrm{C}$

$\Delta \mathrm{Pmax} \leqq 23.3 \mathrm{kPa}$

\subsection{Consideration of Available Reactor Core Design}

The traditional design limits in Japan suggested that the maximum fuel temperature should be lower than $1300{ }^{\circ} \mathrm{C}$. From the engineering judgments, the effective coolant flow rate should be higher than $70 \%$. Thus the design limit of the pressure drop in the core is $23.3 \mathrm{kPa}$, according to the eq. (11) as shown in Figure 10. Table 6 and 7 show the available analysis cases of GT300 and GT600. The available analysis cases in GT300 are case A05, A06, A09, A10, A13, A14, A17, and A18. It means that $1150{ }^{\circ} \mathrm{C}$ of the outlet coolant temperature is available. On the contrary, the available 
analysis case in GT600 is the case A17. It means that $900{ }^{\circ} \mathrm{C}$ of the outlet coolant temperature is available.

\section{Conclusions}

The followings can be concluded:

1. High porosity leads to low fuel maximum temperature.

2. High system pressure leads to low-pressure drop in the core.

3. High porosity leads to low-pressure drop.

4. The available analysis cases in 300MW of thermal power are 8 cases, which indicates that the outlet coolant temperature is lower than $1150^{\circ} \mathrm{C}$.

5. On the contrary, the available analysis case in $600 \mathrm{MW}$ of thermal power is only 1 case, which indicate that the outlet coolant temperature is up to $900{ }^{\circ} \mathrm{C}$.

\section{Nomenclature}

$A_{f}$ : fuel element surface area; $\left(\mathrm{m}^{2}\right)$

$C_{p}$ : coolant heat capacity; $(\mathrm{J} / \mathrm{kgK})$

$H$ : core height; $(\mathrm{m})$

$h$ : heat transfer coefficient; $\left(\mathrm{W} / \mathrm{m}^{2} \mathrm{~K}\right)$

q"': power density; $\left(\mathrm{W} / \mathrm{m}^{3}\right)$

$R$ : core radius; $(\mathrm{m})$

Re: Reynolds number

$T_{f}(z)$ : fuel temperature at the center of fuel element, i.e., the maximum fuel temperature; $\left({ }^{\circ} \mathrm{C}\right)$

$T_{\text {in }}$ : gas inlet temperature; $\left({ }^{\circ} \mathrm{C}\right)$

$T_{\text {out }}$ : gas outlet temperature; $\left({ }^{\circ} \mathrm{C}\right)$

$W_{\text {eff: }}$ effective coolant flow rate, dimensionless value due to the normalization

$z$ : axial distance from the top of the core; $(\mathrm{m})$

$\Delta P$ : pressure drop through the core $(\mathrm{kPa})$

$\Delta P_{a}$ : acceleration pressure drop; $((\mathrm{kPa})$

$\Delta T_{c l}$ : gas temperature increment from inlet to height $z ;\left({ }^{\circ} \mathrm{C}\right)$

$\Delta T_{\text {com }}(z)$ : temperature difference between fuel matrix outer surface and fuel center; $\left({ }^{\circ} \mathrm{C}\right)$
$\Delta T_{\text {film }}(z)$ : temperature difference between fuel element surface and coolant gas at $z ;\left({ }^{\circ} \mathrm{C}\right)$

$\Delta T_{s l}(z)$ : temperature difference between fuel matrix outer surface and fuel element surface; $\left({ }^{\circ} \mathrm{C}\right)$

\section{References}

[1] A Technology Roadmap for Generation IV Nuclear Energy Systems, GIF-002-00, Generation IV International Forum (2002), http://gif.inel.gov/roadmap/

[2] Shusaku SHIOZAWA et al., "The HTTR Project as the World Leader of HTGR Research and Development", J. of AESJ Vol.47, pp. 342-349 (2005)

[3] B.M. HOGLUND,:"UHTREX Operation Near", Vol.9, pp. 1, Power Reactor Technology (1966)

[4] "UHTREX: Alive and Running with Coolant at 2400 oF", Nuclear News (1969)

[5] Progress Report - Pebble Bed Reactor Program, NYO-9071, US Atomic Energy Commission (1960)

[6] M.M.El-Wakil, Nuclear Energy Conversion, Thomas Y. Crowell Company Inc., USA (1982)

[7] M.M El-Wakil, Nuclear Heat Transport, International Textbook Company, USA (1971)

[8] Motoo Fumizawa et al., "Effective Coolant Flow Rate of Flange Type Fuel Element for Very High Temperature Gas-Cooled Reactor ", J. of AESJ Vol.31, pp 828-836 (1989)

[9] Motoo Fumizawa et al., "Preliminary Study for Analysis of Gas-cooled Reactor with Sphere Fuel Element “, AESJ Spring MTG, I66 (2000)

[10] Fumizawa,M.;Nuclear Reactors (ISBN 978-953-51-0967 -9), Edited by Amir Zacarias Mesquita, InTech, pp.177-191 (2013)

[11] Motoo Fumizawa et al., "The Conceptual Design of High Temperature Engineering Test Reactor Upgraded through Utilizing Pebble-in-block Fuel”, JAERI-M 89-222 (1989) 